\title{
Sustainability assessment framework for engineering and sciences educational institutions in developing countries
}

\author{
M. M. G. Elbarkouky ${ }^{1}$, A. M. Aboshady ${ }^{2}$ \& A. S. Salem ${ }^{3}$ \\ ${ }^{1}$ Construction Engineering and Management, School of Business, \\ School of Science and Engineering, \\ The American University in Cairo, Egypt \\ ${ }^{2}$ Structural Engineering Department, Faculty of Engineering, \\ Cairo University, Egypt \\ ${ }^{3}$ Comparative Education and Educational Administration Department, \\ Faculty of Education, Ein Shams University, Egypt
}

\begin{abstract}
There are different factors that may impact the technological, organizational, social, and pedagogical innovation necessary for improving the existing Governmental Egyptian Engineering and Sciences educational institutions to enable offering a more sustainable learning environment for Egyptian students and faculty members. This paper proposes a sustainability assessment framework that can help these educational institutions in achieving the required transformation towards a more sustainable education. First, a literature review is conducted to identify the sustainability factors that need to be considered in achieving a more sustainable education environment in Egypt. Those factors are then tailored to satisfy the Egyptian educational environment through experts' interviews and gap analysis. The factors are then ranked through a survey questionnaire and experts' judgment using a 5-point Likert scale to identify the most significant factors, based on the Pareto principal. A case study of a learning institution in Egypt is adapted to identify the gaps in light of the highly prioritized factors in order to develop guidelines and provide recommendations for improvement.

Keywords: sustainable education, engineering and sciences, pedagogical innovation, gap analysis.
\end{abstract}




\section{Introduction}

In general, sustainability education is considered one of the most critical aspects of education that may hinder the future of a nation. Today's graduates will take the positions of future management, and leadership in any given society, and they will be in need to acquire knowledge and decisions to make correct choices. They should be coupled with information about their society, economy, and environmental issue that change dramatically year over year. Plank [1] stated that education for sustainability development aims at enabling everyone to gain the values, skills, and knowledge, which contribute to building more sustainable society. This implies revising teaching content to respond to global and local challenges. It should also promote teaching methods that enable students to grasp skills, such as interdisciplinary thinking, integrated planning, understanding complexities, cooperating with others in decision-making process, and participating in local, national, and global processes towards sustainable development. Also, Simpson [2] suggested that higher education has a tremendous contribution to enhance sustainability development. For example, University researchers were the first to alert the global warming issue, and researchers are now seeking to find technological and social solutions to assist nations to face this environmental challenge. Therefore, higher education institutions should play their part as centres of teaching and research in their local communities.

\section{Literature review}

According to the World Commission on Environment and Development [3], sustainable development was defined as "development that meets the needs of the present without compromising the ability of future generations to meet their own needs." Different researchers have tackled the issue of sustainability education. Cole [4] assessed sustainability on a Canadian University Campus. He proposed a framework for the development of Victoria Campus sustainability assessment. West et al. [5] recommended international perspectives to flourish the quality in higher education for educational research. Martin et al. [6] studied sustainability development in higher education. He proposed some recommendations for future development, such as universities should function as places of research and learning for sustainable development. Also, he proposed that new sustainable development strategy means securing the future, which emphasis the role that education can play in both raising awareness among youth about sustainability development as well as giving them the skills apply sustainability development into practice. Wigmore and Ruiz [7] developed a sustainability assessment framework in higher education institutions. Kaviola and Rochmeder [8] studied sustainability development in higher education in Finland. Koehn and Demment [9] overviewed higher education and sustainability development in Africa. Zilaly [10] investigated the role of higher education and recommended a clean technologies, and environmental policy toward enhancing the higher educational institutions. In addition, some authors have studied the factors affecting 
Sustainability development. Evans et al. [11] assessed the sustainability indicators that affect the renewable energy technologies. Ghose [12] technological challenges for boosting coal production with environmental Sustainability. Urban et al. [13] designed self-reliant networks of technological ecological systems. Smith [14] studied the organizational elements affecting Sustainability. Pluye et al. [15] designed a program for sustainability, which focuses on organizational routines. Smith [16] highlighted the importance of organizational learning for Sustainability. Gonzalès and Parrott [17] developed a network theory for the assessment of Sustainability of Socio-Ecological Systems. Assefa and Frostell [18] studied social sustainability and social acceptance in technology assessment. Daniel et al. [19] discussed social Sustainability in urban renewal communities. Yuen et al. [20] developed a comparative case study for the pedagogical orientation in Hong Kong. Finally, Johansson [21] discussed Pedagogical approaches and their implications for sustainability. All the above researchers did not develop a framework that deals with the sustainability development of the Engineering and Science Institutions in Egypt. Therefore, the Sustainability assessment framework was developed in this paper to overcome this limitation and provide recommendations not only applicable to Egypt, but also to any other developing country.

\section{Objectives}

The main objective of this paper is to prioritize critical factors affecting sustainability development in Egypt. This is achieved through the development of the sustainability development framework. The consent of framework development can be generalized and applied to other countries by changing related sustainability development factors and expert opinions. The framework solves a major problem that faces educators who want to prioritize critical factors affecting the sustainability development process in order to produce a list of prioritized sustainability factors.

\section{Methodology and model development}

The proposed framework is composed of six stages: Identifying critical Sustainability Factors, Creating Linguistic Scale to Rate Different Critical Factors and Collecting Experts' Opinions, Performing Statistical Analysis, Assessing the Relative Importance Index (RII) for Prioritization, Conducting a Case Study in Egypt, and Suggesting Recommendations as per in Figure 1.

\subsection{Identifying Critical Sustainability Development Factors}

Critical Sustainability Development Factors were determined using literature review and interviews with ten experts each of them had twenty years of experience in Sustainability Development Education. Experts agreed that Sustainability Development Factors can be divided into four groups: Technological Factors, Organizational Factors, Social Factors, and Pedagogical Innovation Factors (Table 1). 


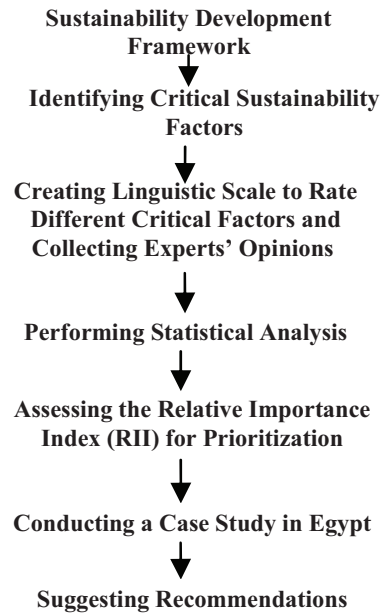

Figure 1: $\quad$ Methodology and model development.

Table 1: Critical sustainability development factors and their groups.

\begin{tabular}{|c|c|c|c|}
\hline \multicolumn{2}{|r|}{ Group (1) Technological factors } & \multicolumn{2}{|r|}{ Group (3) Social factors } \\
\hline 1 & Need for acquiring skills for developed industries & 21 & $\begin{array}{l}\text { Ensure participation of different groups (students, } \\
\text { women) in social activities }\end{array}$ \\
\hline 2 & $\begin{array}{l}\text { Enhance university's curriculum with main } \\
\text { changes in energy resource }\end{array}$ & 22 & $\begin{array}{l}\text { Being aware of environmental injustice and its direct } \\
\text { and indirect effects on higher education }\end{array}$ \\
\hline 3 & Enhance students' creativity & 23 & Understand internationalization of core curriculum \\
\hline 4 & $\begin{array}{l}\text { Promote the higher education requirements for } \\
\text { radical improvement in human technology } \\
\text { interfaces }\end{array}$ & 24 & Promote lifelong learning \\
\hline 5 & $\begin{array}{l}\text { Aware the staff about changing in technological } \\
\text { skills to enhance these skills in students. }\end{array}$ & 25 & Prepare students to post graduation life \\
\hline 6 & Establish vocational courses & 26 & Monitor and evaluate team performance \\
\hline 7 & $\begin{array}{l}\text { Teach students giving positive respond to global } \\
\text { and local challenges }\end{array}$ & 27 & $\begin{array}{l}\text { Need to avoid in equality within nations and develop } \\
\text { internationally recognized curriculum }\end{array}$ \\
\hline 8 & $\begin{array}{c}\text { Prepare students to the technological effects on } \\
\text { employment }\end{array}$ & 28 & Promote community engagement \\
\hline 9 & $\begin{array}{l}\text { Understand technology and its negative and } \\
\text { positive effect on our daily life }\end{array}$ & 29 & Implement the university policies \\
\hline 10 & Enhance industry intervention in higher education & 30 & Need to have the ability to work well with others \\
\hline \multicolumn{2}{|r|}{ Group (2) Organizational factors } & \multicolumn{2}{|r|}{ Group (4) Pedagogical innovation factors } \\
\hline 11 & $\begin{array}{l}\text { Need to face the deficit in real demands in goods } \\
\text { and services existed in industrial organizations. }\end{array}$ & 31 & Need for distance learning \\
\hline 12 & $\begin{array}{c}\text { Enhance students' loyalty to working } \\
\text { organizations. }\end{array}$ & 32 & Need for industries involvement in research \\
\hline 13 & $\begin{array}{c}\text { Need to know about employment terms and } \\
\text { conditions }\end{array}$ & 33 & Need for graduating innovative students \\
\hline 14 & Need to be aware about number of job vacancies & 34 & Being aware with changing nature of market needs \\
\hline 15 & $\begin{array}{c}\text { Promote skills understanding between students } \\
\text { and staff }\end{array}$ & 35 & $\begin{array}{l}\text { Need for providing training to deans and chairs } \\
\text { to their work }\end{array}$ \\
\hline 16 & Learn students how to solve problems & 36 & Need for gaining worldwide accreditation \\
\hline 17 & Develop and run international offices & 37 & Promote experiences in labor market research \\
\hline 18 & $\begin{array}{l}\text { Need to cope with international division of labour } \\
\text { market and its effects in industrial organizations. }\end{array}$ & 38 & Being aware of economic challenges for $21^{\text {st }}$ century \\
\hline 19 & $\begin{array}{l}\text { Being aware of financing development and } \\
\text { growth }\end{array}$ & 39 & Giving rise to international equity \\
\hline 20 & Support learning for life and work & 40 & $\begin{array}{l}\text { Develop staff to cope with international education } \\
\text { standards }\end{array}$ \\
\hline
\end{tabular}




\subsection{Creating Linguistic Scale to Rate Different Critical Factors and collecting experts' opinions}

In this step, a survey-based questionnaire was designed to assist experts in ranking Critical Sustainability Development Factors based on the impact of these Sustainability Development factors on the sustainable education enhancement of engineering and science educational institutions, using a five-point Likert scale (Saaty [22]). The scale ranged between (1) Very Low and (5) Very High, while the term (3) Medium was placed as a midterm value on the scale. Moreover, the questionnaire included a section that contained experts' demographic information that defined five qualification criteria of experts: Q1: Years of experience, Q2: Years of experience in Science or education Fields, Q3: Position, Q4: Academic record, and Q5: Public vs. Private Institutions. Table 2 lists experts' qualifications and their attributes.

\subsection{Performing statistical analysis}

The statistical analysis of the experts' ratings determined the Mean, Median, Mode, Standard Deviation, Standard Error, and 95\% Confidence Range to advise on whether the opinions are converging or not. The 95\% Confidence Range is a type of interval estimate of a population parameter and is used to indicate the reliability of an estimate, where the 95\% Confidence Range reflects a significance level of 0.05 in the current study. The Standard Error was computed to measure the extent to which the means from different samples is expected to vary from the population mean, owing to the chance error in the sampling process, which was computed by dividing the Standard Deviation by the square root of $\mathrm{N}$, where $\mathrm{N}$ is the sample size. According to Montgomery [23], computing the Standard Error implies an acceptable agreement among experts. Abdelgawad [24] demonstrated that the calculated Standard Error is to be compared to 0.2 , as this value indicates a relatively precise point estimate of agreement among experts on the results (Shen et al. [25]).

\subsection{Assessing the Relative Importance Index (RII) for prioritization}

In this step, the Relative Importance Index (RII) was utilized to prioritize Critical Sustainability Development Factors, based on the ranking of the experts (collected from step 2). This approach was applied because of its simplicity and ability to provide subjective and objective assessments of multiple factors (Elbarkouky et al. [26]).

The average rating of the fifty experts (Table 2) who participated in the process of prioritizing Critical Sustainability Development Factors was computed. 'Equation (1)' illustrates the RII computation.

$$
R I I j=\sum_{\mathrm{i}=1}^{\mathrm{n}} \frac{\mathrm{y} j}{\mathrm{z}}
$$

where, $y j$ is the rating score assigned to each risk event $(j)$ by each expert $(i)$ on the Likert scale from 1 to 5 , and $z$ is the highest possible rating value of the 
Likert scale [22], which is 5 in this case. The RII value has a range between 0 to 1 (0 not inclusive), such that the higher its value, the more important the risk event is.

Table 2: $\quad$ Experts’ qualifications (attributes).

\begin{tabular}{|c|c|c|c|c|c|}
\hline $\begin{array}{c}\text { Expert } \\
\text { No. }\end{array}$ & $\begin{array}{c}\mathbf{Q 1} \\
\text { Years of } \\
\text { Experience }\end{array}$ & $\begin{array}{c}\text { Q2 } \\
\text { Years in } \\
\text { Education or } \\
\text { Science Fields }\end{array}$ & $\begin{array}{c}\text { Q3 } \\
\text { Position }\end{array}$ & $\begin{array}{c}\text { Q4 } \\
\text { Academic } \\
\text { record }\end{array}$ & $\begin{array}{c}\text { Q5 } \\
\text { Public vs. Private }\end{array}$ \\
\hline 1 & $11-15$ & $6-10$ & Professor & PhD & Public \\
\hline 2 & $11-15$ & $6-10$ & Professor & $\mathrm{PhD}$ & Public \\
\hline 3 & $11-15$ & $6-10$ & Assco Prof & $\mathrm{PhD}$ & Public \\
\hline 4 & $11-15$ & $11-15$ & Assco Prof & PhD & Public \\
\hline 5 & $11-15$ & $6-10$ & Assco Prof & $\mathrm{PhD}$ & Public \\
\hline 6 & $11-15$ & $6-10$ & Assco Prof & PhD & Public \\
\hline 7 & $6-10$ & $6-10$ & Assco Prof & PhD & Public \\
\hline 8 & $1-5$ & $<1$ & Ass Prof & PhD & Public \\
\hline 9 & $1-5$ & $1-5$ & Ass Prof & PhD & Public \\
\hline 10 & $<1$ & $<1$ & Ass Prof & $\mathrm{PhD}$ & Public \\
\hline 11 & $1-5$ & $<1$ & Ass Prof & PhD & Public \\
\hline 12 & $1-5$ & $1-5$ & Ass Prof & $\mathrm{PhD}$ & Public \\
\hline 13 & $16-20$ & $16-20$ & Professor & PhD & Public \\
\hline 14 & $16-20$ & $16-20$ & Professor & $\mathrm{PhD}$ & Public \\
\hline 15 & $11-15$ & $11-15$ & Professor & $\mathrm{PhD}$ & Public \\
\hline 16 & $16-20$ & $16-20$ & Professor & PhD & Public \\
\hline 17 & $16-20$ & $11-15$ & Professor & PhD & Public \\
\hline 18 & $11-15$ & $6-10$ & Assco Prof & $\mathrm{PhD}$ & Public \\
\hline 19 & $<1$ & $<1$ & Ass Prof & $\mathrm{PhD}$ & Public \\
\hline 20 & $16-20$ & $11-15$ & Professor & $\mathrm{PhD}$ & Public \\
\hline 21 & $11-15$ & $6-10$ & Assco Prof & $\mathrm{PhD}$ & Public \\
\hline 22 & $1-5$ & $1-5$ & Ass Prof & $\mathrm{PhD}$ & Public \\
\hline 23 & $1-5$ & $<1$ & Ass Prof & PhD & Public \\
\hline 24 & $1-5$ & $<1$ & Ass Prof & $\mathrm{PhD}$ & Public \\
\hline 25 & $1-5$ & $1-5$ & Ass Prof & $\mathrm{PhD}$ & Public \\
\hline 26 & $16-20$ & $16-20$ & Professor & PhD & Public \\
\hline 27 & $16-20$ & $16-20$ & Professor & PhD & Public \\
\hline 28 & $6-10$ & $6-10$ & Assco Prof & PhD & Public \\
\hline 29 & $16-20$ & $16-20$ & Professor & PhD & Public \\
\hline 30 & $6-10$ & $6-10$ & Assco Prof & PhD & Public \\
\hline 31 & $16-20$ & $16-20$ & Professor & PhD & Private \\
\hline 32 & $6-10$ & $6-10$ & Ass Prof & PhD & Private \\
\hline 33 & $1-5$ & $1-5$ & TA & Master & Private \\
\hline 34 & $16-20$ & $16-20$ & Professor & $\mathrm{PhD}$ & Private \\
\hline 35 & $1-5$ & $<1$ & TA & Master & Private \\
\hline 36 & $16-20$ & $11-15$ & PM & Master & Private \\
\hline 37 & $1-5$ & $<1$ & SPE & Bachelor & Private \\
\hline 38 & $16-20$ & $16-20$ & PM & Master & Private \\
\hline 39 & $16-20$ & $16-20$ & PM & Master & Private \\
\hline 40 & $1-5$ & $1-5$ & SPE & Master & Private \\
\hline 41 & $11-15$ & $6-10$ & SPE & Bachelor & Private \\
\hline 42 & $16-20$ & $11-15$ & $\mathrm{PM}$ & Bachelor & Private \\
\hline 43 & $16-20$ & $16-20$ & PM & Master & Private \\
\hline 44 & $11-15$ & $6-10$ & PM & Bachelor & Private \\
\hline 45 & $11-15$ & $6-10$ & PM & Master & Private \\
\hline 46 & $6-10$ & $1-5$ & SPE & Bachelor & Private \\
\hline 47 & $11-15$ & $11-15$ & PM & Bachelor & Private \\
\hline 48 & $11-15$ & $11-15$ & PM & Bachelor & Private \\
\hline 49 & $11-15$ & $11-15$ & SPE & Master & Private \\
\hline 50 & $16-20$ & $6-10$ & PM & Master & Private \\
\hline
\end{tabular}

As illustrated in Table 2, the PM stands for Project Manager, SPE stands for Senior Project Engineer, Ass Prof stands for Assistant Professor, Assco Prof stands for Associate Professor and TA stands for Teaching Assistant. 


\section{Conducting a case study in Egypt (Ain Shams University)}

Sustainability development plays a vital role in enhancing the understanding of youth and developing there needed skills in order to be able to cope with the changes in the technological, economical, and social requirement. The Sustainability assessment framework was applied in this case study to be able to identify and qualify the factors affecting the development of the sustainability objectives. Case study is conducted on Ain Shams University, which is public university, and is considered as one the biggest universities in the field of Engineering and Science, and 6 October University, which is a private university and considered one of the most growing private universities in Egypt.

The forty sustainability factors that have been previously identified in step 1 of the framework were introduced to fifty Egyptian experts to solicit their opinions regarding the linguistic criticality of factors that would affect the development of sustainability objectives. The survey was conducted using the linguistic rating scales and questionnaire-based survey (step 2). The experts were carefully selected to possess different levels of experience, represent different sizes and maintain different experience levels in sustainability. The statistical Analysis was performed in (Step 3) in order to ensure the correctness of the data collected from experts, and to ensure that their final assessment is a result of common agreement. The Relative Importance Index (RII) was computed using equation (1) Step 5 to rank different factors affecting the sustainability development based on their consequence on sustainability assessment. Table 3 illustrates the computations of the Mean, Median, Mode, Standard Deviation, 95\% Confidence Range, Average Rating, Relative Importance Index (RII), and rank of different factors.

\section{Recommendations}

A set of recommendations were developed to enhance the sustainability development using literature review and interviews with experts with fifty experts.

1. Graduates' skills should be developed in order to meet the needs of the modernized industries.

2. Both university curricula and methods of teaching should be examined in order to improve the mentality of the students, and cope with the radical technological changes.

3. Higher education institutions have to include local and global challenges in their curriculum, and motivate students to learn how to respond to these challenges positively.

4. Higher education institutions have to aware students about the changing demands of employment, and labor markets.

5. Higher education institutions have to contain international offices for

6. Famous universities in order to acquire a variety of knowledge.

7. Team work skills should be strengthened within the university

8. Curriculum in order to develop students' skills in this field. 
Table 3: $\quad$ List of prioritized sustainability development factors.

\begin{tabular}{|c|c|c|c|c|c|c|c|c|}
\hline $\begin{array}{l}\text { Factors } \\
\text { ID }\end{array}$ & Mean & Median & Mode & $\begin{array}{l}\text { Standard } \\
\text { Deviation }\end{array}$ & $\begin{array}{c}\text { Standard } \\
\text { Error }\end{array}$ & $\begin{array}{c}95 \% \text { Confidence } \\
\text { Range }\end{array}$ & RII & Rank \\
\hline 19 & 4.88 & 5 & 5 & 0.385 & 0.088 & {$[5.035,4.725]$} & 0.976 & 1 \\
\hline 15 & 4.76 & 5 & 5 & 0.591 & 0.109 & {$[4.952,4.568]$} & 0.952 & 2 \\
\hline 2 & 4.7 & 5 & 5 & 0.505 & 0.1 & {$[4.876,4.524]$} & 0.94 & 3 \\
\hline 26 & 4.68 & 5 & 5 & 0.471 & 0.097 & {$[4.851,4.509]$} & 0.936 & 4 \\
\hline 1 & 4.56 & 5 & 5 & 0.501 & 0.1 & {$[4.736,4.384]$} & 0.912 & 5 \\
\hline 7 & 4.5 & 5 & 5 & 0.814 & 0.128 & {$[4.725,4.275]$} & 0.9 & 6 \\
\hline 39 & 4.48 & 4.5 & 5 & 0.544 & 0.104 & {$[4.663,4.297]$} & 0.896 & 7 \\
\hline 18 & 4.46 & 5 & 5 & 0.788 & 0.126 & {$[4.682,4.238]$} & 0.892 & 8 \\
\hline 29 & 4.46 & 5 & 5 & 0.734 & 0.121 & {$[4.673,4.247]$} & 0.892 & 8 \\
\hline 34 & 4.46 & 5 & 5 & 0.762 & 0.123 & {$[4.677,4.243]$} & 0.892 & 8 \\
\hline 33 & 4.44 & 5 & 5 & 0.705 & 0.119 & {$[4.65,4.23]$} & 0.888 & 9 \\
\hline 11 & 4.42 & 5 & 5 & 0.758 & 0.123 & {$[4.637,4.203]$} & 0.884 & 10 \\
\hline 24 & 4.42 & 5 & 5 & 0.731 & 0.121 & {$[4.633,4.207]$} & 0.884 & 10 \\
\hline 40 & 4.42 & 5 & 5 & 0.859 & 0.131 & {$[4.651,4.189]$} & 0.884 & 10 \\
\hline 4 & 4.38 & 4.5 & 5 & 0.697 & 0.118 & {$[4.588,4.172]$} & 0.876 & 11 \\
\hline 10 & 4.36 & 4 & 5 & 0.693 & 0.118 & {$[4.568,4.152]$} & 0.872 & 12 \\
\hline 5 & 4.3 & 5 & 5 & 0.814 & 0.128 & {$[4.525,4.075]$} & 0.86 & 13 \\
\hline 8 & 4.3 & 4 & 4 & 0.463 & 0.096 & {$[4.469,4.131]$} & 0.86 & 13 \\
\hline 30 & 4.26 & 4 & 4 & 0.723 & 0.12 & {$[4.471,4.049]$} & 0.852 & 14 \\
\hline 3 & 4.24 & 4 & 4 & 0.687 & 0.117 & {$[4.446,4.034]$} & 0.848 & 15 \\
\hline 9 & 4.14 & 4 & 5 & 0.783 & 0.125 & {$[4.36,3.92]$} & 0.828 & 16 \\
\hline 24 & 4.12 & 4 & 4 & 0.659 & 0.115 & {$[4.323,3.917]$} & 0.824 & 17 \\
\hline 27 & 4.1 & 4.5 & 5 & 1.111 & 0.149 & {$[4.362,3.838]$} & 0.82 & 18 \\
\hline 6 & 4.08 & 4 & 4 & 0.778 & 0.125 & {$[4.3,3.86]$} & 0.816 & 19 \\
\hline 32 & 4.06 & 4 & 4 & 0.512 & 0.101 & {$[4.238,3.882]$} & 0.812 & 20 \\
\hline 35 & 4.06 & 4 & 5 & 0.818 & 0.128 & {$[4.285,3.835]$} & 0.812 & 20 \\
\hline 37 & 4.06 & 4 & 5 & 0.89 & 0.133 & {$[4.294,3.826]$} & 0.812 & 20 \\
\hline 16 & 4.04 & 4 & 4 & 0.832 & 0.129 & {$[4.267,3.813]$} & 0.808 & 21 \\
\hline 20 & 4.02 & 4 & 4 & 0.795 & 0.126 & {$[4.242,3.798]$} & 0.804 & 22 \\
\hline 13 & 3.98 & 4 & 5 & 0.958 & 0.138 & {$[4.223,3.737]$} & 0.796 & 23 \\
\hline 38 & 3.98 & 4 & 4 & 0.82 & 0.128 & {$[4.205,3.755]$} & 0.796 & 23 \\
\hline 31 & 3.96 & 4 & 3 & 0.925 & 0.136 & {$[4.199,3.721]$} & 0.792 & 24 \\
\hline 28 & 3.92 & 4 & 4 & 1.085 & 0.147 & {$[4.179,3.661]$} & 0.784 & 25 \\
\hline 12 & 3.92 & 4 & 4 & 1.027 & 0.143 & {$[4.172,3.668]$} & 0.784 & 25 \\
\hline 14 & 3.86 & 4 & 4 & 0.729 & 0.121 & {$[4.073,3.647]$} & 0.772 & 26 \\
\hline 17 & 3.78 & 4 & 4 & 0.815 & 0.128 & {$[4.005,3.555]$} & 0.756 & 27 \\
\hline 22 & 3.78 & 4 & 5 & 1.148 & 0.152 & {$[4.048,3.512]$} & 0.756 & 27 \\
\hline 36 & 3.68 & 4 & 3 & 0.683 & 0.117 & {$[3.886,3.474]$} & 0.736 & 28 \\
\hline 21 & 3.52 & 4 & 5 & 1.474 & 0.172 & {$[3.823,3.217]$} & 0.704 & 29 \\
\hline 23 & 3.18 & 4 & 4 & 0.919 & 0.136 & {$[3.419,2.941]$} & 0.636 & 30 \\
\hline
\end{tabular}

9. Administration in Universities should aware the staff and faculty members about financing development and the rate of growth in order to provide this experience to students.

10. Universities have to provide social services, and social activities, and advice students to participate in this field.

11. Higher education institutions have to promote lifelong learning.

12. Higher education institutions have to aware students about post graduation life, and how to develop their skills.

13. Universalities have to develop internationally recognized curriculum.

14. Higher education institutions have to develop students' skills in order to obtain finally an innovative graduate. 
15. Universities should have a linkage with international organizations, such as UNESCO, International Bank, and International Monetary Fund in order to achieve worldwide accreditation.

16. Universities have to promote research activities in the field of international education.

17. Universities have to develop their staff to cope with international education standards.

\section{Conclusion}

A Sustainability Assessment Framework was developed in this paper to prioritize different factors affecting the development of Sustainability objective. The proposed framework was composed of six stages: Identifying critical Sustainability Factors, Creating Linguistic Scale to Rate Different Critical Factors ,and Collecting Experts' Opinions, Performing Statistical Analysis, Assessing the Relative Importance Index (RII) for Prioritization, Conducting a Case Study in Egypt, and Suggesting Recommendations. Factors affecting the sustainability development were identified using literature review and interviews with experts. A case study was conducted to demonstrate the validity of the Sustainability assessment framework in identifying, and qualifying different factors affecting the sustainability development. The framework provided an improvement over previous sustainability models by incorporating the use of the Relative Importance Index (RII) to prioritize different factors affecting the sustainability development. The framework improves over the previous models, which rely on the subjective assessment. In the future, the highly prioritized sustainability factors will be introduced to another quantitative sustainability assessment model that quantify these factors that is currently under preparation.

\section{References}

[1] Plank, D., "The Emerging Markets and Higher Education: Development and Sustainability”, Economics of Education, 22(3), 337-338, 2003.

[2] Simpson, J., "A Shared Vision for Development in Higher Education", Higher Education Funding Council for England, www.sd.defra.gov.uk, 2010.

[3] The World Commission on Environment and Development (WCED), Our common future. Oxford, Oxford University Press, May 21, 1987.

[4] Cole, L., "Assessing Sustainability on Canadian University Campus: Development of a Campus Sustainability Assessment Framework", University of Victoria, Canada, www.neumann.hec.ca/.../campus.../ campus_memoire.pdf, 2003.

[5] West, A., Noden, P. and Gosling, R. "Quality in Higher Education; An international Perspective", Centre for Educational Research London School of Economics and Political Sciences, www. citeseerx.ist.psu.edu, 2000. 
[6] Martin, S., Dawe, G., and Jucker, R. "Sustainable Development in Higher Education Current Practice and Future Development”, Higher Education Academy, UK, www._thesite.eu/sustdevinHEfinalreport.pdf, 2005.

[7] Wigmore, A. and Ruiz, M. "Sustainability Assessment in Higher Education Institutions”, Romonllull Journal of Applied Ethics, 1(1), 25-42, 2010.

[8] Kaviola, T., and Rochmeder, L. "Towards Sustainable Development in Higher Education”, Ministry of Education, Department for Education and Science Policy, Finland, www.minedu.fi/export/sites/default/.../opm06.pdf, 2007.

[9] Koehn, P.H. and Demment, M.W. "Higher Education and Sustainable Development in Africa and Why Partner Transnational?”, Paper for the Ministerial Conference on Higher Education in Agriculture in Africa, Kampala, www.aplu.org, 2010.

[10] Zilaly, G. “Towards Sustainability: The Role of Higher Education”, Clean Technologies and Environmental Policy, 8(1), 1-2, 2006.

[11] Evans, A., Strezov, V. and Evans, T.J., "Assessment of sustainability indicators for renewable energy technologies”, Renewable and Sustainable Energy Reviews, 13(5),1082-1088, 2009.

[12] Ghose, M.K. "Technological challenges for boosting coal production with environmental sustainability”, Environmental monitoring and assessment, 154(1-4), 373-381, 2009.

[13] Urban, R.A., Bakshi, B.R., Grubb, G.F., Baral, A. and Mitsch, W.J. "Towards sustainability of engineered processes: Designing self-reliant networks of technological-ecological systems”, Computers and Chemical Engineering, 34(9), 1413-1420, 2010.

[14] Smith, P.A.C. "Elements of organizational sustainability”, The Learning Organization, 18(1), 5-9, 2011.

[15] Pluye, P., Potvin, L., Denis, J.L. and Pelletier, J. "Program sustainability: focus on organizational routines”, Health Promotion International, 19(4), 489-500, 2004.

[16] Smith, P.A.C. “The importance of organizational learning for organizational sustainability”, The Learning Organization, 19(1), 4-10, 2012.

[17] Gonzalès, R. and Parrott, L. "Network Theory in the Assessment of the Sustainability of Social-Ecological Systems”, Geography Compass, 6(2), 76-88, 2012.

[18] Assefa, G. and Frostell, B. "Social sustainability and social acceptance in technology assessment: A case study of energy technologies”, Technology in Society, 29(1), 63-78, 2007.

[19] Daniel C.W.H., Yung, Y., Chi K.L., Sun W.P., Hak K.Y. and Ervi L. "Social sustainability in urban renewal: An assessment of community aspirations”, Urbani Izziv, 23(1), 125-139, 2012.

[20] Yuen, A.H.K., Lee, M.W. and Law, N. "School leadership and teachers' pedagogical orientations in Hong Kong: A comparative perspective”, Education and Information Technologies, 14(4), 381-396, 2009. 
[21] Johansson, T. "Pedagogical approaches and their implications for sustainability”, EUROGEO Seminar and Annual Meeting Sustainable Geographies, University of Helsinki, 1-17, 2010.

[22] Saaty, T.L. Multi-criteria Decision Making: The Analytic Hierarchy Process. RWS Publications, Pittsburgh, PA, 1980.

[23] Montgomery, D.C., Runger, G.C. and Hubele, N.F. Engineering Statistics, John Wiley and Sons, New York, 1998.

[24] Abdelgawad, M. "Construction Schedule Delay Assessment in Joint Venture Projects: A Fuzzy Logic Method" Master of Science Thesis, Structural Engineering Department, Cairo University, Egypt, 2005.

[25] Shen, L.Y., Wu, G.W.C. and Ng, C.S.K. "Risk Assessment for Construction Joint Ventures in China." Journal of Construction Engineering and Management, 127(1), 76-81, 2001.

[26] Elbarkouky, M.G., Ezzeldin, A.S. and Elassaly, A. A multi-criteria decision-making (MCDM) framework for prioritizing damaged infrastructure and services facilities in Egypt using sustainability objectives. Proceedings, CSCE Annual Conference, 1st International Specialty Conference on Sustaining Public Infrastructure, Edmonton, Alberta, June 6-9, 2012, INF-S11-1011-1/11, 2012. 